\title{
Molecular Epidemiological Study of Hepatitis B Virus in the United Arab Emirates Based on the Analysis of Pre-S Gene
}

Mubarak S. Alfaresi

Department of Pathology and Laboratory Medicine, Zayed Military Hospital, Abu Dhabi, UAE

\begin{abstract}
This study was undertaken to investigate the prevalence of the hepatitis B virus (HBV) variant with the pre-S mutant circulating in the United Arab Emirates (UAE). The sequences of the pre-S and $S$ regions were determined in serum samples of 90 HBV DNA-positive subjects who had been enrolled in the study. The results showed that genotypes $\mathrm{D}$ and $\mathrm{A}$ accounted for $77.8 \%$ and $17.8 \%$ respectively. The distribution of the HBV antigen subtypes was: ayw2 $(78.9 \%)$, adw2 (14.4\%), and adw (2.2\%). Sequencing analysis showed that pre-S mutations were present in 4 samples $(4.4 \%)$, with pre-S2 deletion as the most common mutant $(50 \%)$. The pre-S mutations were associated with older age and a higher mean HBV DNA level. The study demonstrated that HBV genotypes D and A were the predominant strains circulating in the UAE and that the HBV pre-S mutant is very rare in this area, appearing only in genotype $\mathrm{C}$.
\end{abstract}

Keywords: Hepatitis B virus; Genotype; Pre-S mutation; UAE

\section{Introduction}

Hepatitis B virus (HBV) is a small, enveloped $3.2 \mathrm{~kb}$ DNA virus with four Open Reading Frames (ORFs). HBV envelope proteins are encoded by three overlapping envelope genes contained within a single ORF: pre-S1, pre-S2, and S. Depending on the translated initiation site among S, pre-S2, or pre-S1, three different sized proteins are produced: a small hepatitis B surface protein (small HBs) containing 226 amino acid residues; a middle hepatitis B surface protein (middle HBs) containing 55 additional amino acid residues; and a large hepatitis B surface protein (large HBs) containing 108 or 119 additional amino acid residues, depending on the serotype. The pre-S region mediates hepatocyte attachment of the virus (amino acids 21 to 47 in pre-S1) [1-4], contains B-cell and T-cell epitopes [5-7] and a binding site for neutralising anti pre-S2 antibody (amino acids 120 to 145 ) $[1,3,4]$ and has an S promoter for controlling the production of middle HBs and small HBs.

In the late 1990s, two major types of pre-S deletion mutant LHBS were identified and highly associated with Hepatocellular carcinoma (HCC) $[8,9]$. LHBS is expressed primarily at the late stage of chronic HBV infection, after the viral genome has integrated into the host chromosome [10-13]. Pre-S mutant LHBS was first isolated from ground glass hepatocytes (GGH), the histological hallmarks of the late stages of chronic HBV infection, and is often seen in the liver sections of HCC patients [14]. Pre-S mutant LHBS is highly associated with advanced liver diseases, including cirrhosis and HCC, which suggests that it contributes to hepatocellular carcinogenesis [15-23].

After pre-S mutant LHBS was discovered, various geographically diverse studies [15-23] screening for pre-S mutations invariably reported that they were prevalent in chronic HBV carriers. In addition, pre-S mutant LHBS, especially the pre-S2 type, is highly correlated with the severity of HBV-related liver diseases, including HCC [15-18,20]. Therefore, it is important to screen for pre-S deletion mutations in chronic HBV carriers. This type of screening should be done in combination with the detection of other HBV markers, such as viral titers and $\mathrm{HBe}$ antigen (Ag), to estimate an HBV carrier's relative risk for HCC.

In this study, we investigated the prevalence and characteristics of the pre-S gene mutations predominant in the United Arab Emirates population as well as its association with HBV genotypes and both precore and core mutants.

\section{Materials and Methods}

A total of 120 consecutive serum samples from HBs Ag-positive patients were evaluated in this study. These samples were derived from 98 males and 22 females with a mean age of $36.4 \pm 12.6$ years (range: 18 to 70 years). All of these patients were UAE citizens. Serum samples were stored at $-20^{\circ} \mathrm{C}$ and thawed immediately before use. The samples were evaluated for the presence of several serological markers of HBV infection (including $\mathrm{HBe} \mathrm{Ag}$, anti-HBe Ag, and $\mathrm{HBs} \mathrm{Ag}$ ) using the bioMérieux ELISA kit according to the manufacturer's instructions.

\section{Detection of HBV-DNA by PCR (Polymerase Chain Reaction)}

The extraction and amplification of HBV-DNA was carried out by nested PCR using the methods described by Kaneko et al. [24].

\section{Analysis of $\mathrm{HBV}$ sequences from different genotypes}

We used selected primers that have been described previously [25] and that corresponded to conserved regions of the various HBV genotypes that flank heterogeneous intervening regions to distinguish between the HBV genotypes. The region selected for amplification also included the amino acid loop corresponding to the $\mathrm{a}, \mathrm{d} / \mathrm{y}$, and $\mathrm{w} / \mathrm{r}$ allelic subtypic determinants as well as mutations that have been shown to be related to the HBIg antibody, the anti-HBs monoclonal antibody, and vaccine resistance. The following primers were selected: 1) FHBS1, 5'-GAG TCT AGA CTC GTG GTG GAC TTC-3';2) FHBS2, 5'-CGT GGT GGA CTT CTC TCA ATT TTC-3'; 3) RHBS1, 5'-AAATKG CAC TAG TAA ACT GAG CCA-3'; and 4) RHBS2, 5'-GCC ARG AGA AAC GGR CTG AGG CCC-3'. The positions in the HBV genome (strain HBVADW; GenBank accession number V00866) to which the primers

*Corresponding author: Mubarak S. Alfaresi, Department of Pathology and Laboratory Medicine, Zayed Military Hospital, Abu Dhabi, UAE, Tel: +97124055489; Fax: +9712-4492075; E-mail: uaenow@eim.ae

Received April 19, 2012; Accepted June 24, 2012; Published June 30, 2012

Citation: Alfaresi MS (2012) Molecular Epidemiological Study of Hepatitis B Virus in the United Arab Emirates Based on the Analysis of Pre-S Gene. J Med Microb Diagn 1:113. doi:10.4172/2161-0703.1000113

Copyright: (c) 2012 Alfaresi MS. This is an open-access article distributed under the terms of the Creative Commons Attribution License, which permits unrestricted use, distribution, and reproduction in any medium, provided the original author and source are credited. 
corresponded were as follows: 1) HBS1F (positions 244 to 267), 2) HBS2F (positions 255 to 278), 3) HBS2R (positions 648 to 671), and 4) HBS1R (positions 668 to 691). Serum samples were treated as described above and subjected to two rounds of amplification sequentially with outer (FHBS1 and RHBS1) and inner (FHBS2 and RHBS2) primers. The amplification conditions for the two rounds of the nested PCR were as follows: initial denaturation at $94^{\circ} \mathrm{C}$ for $20 \mathrm{~s}$, followed by 30 cycles of amplification at $94^{\circ} \mathrm{C}$ for $20 \mathrm{~s}, 56^{\circ} \mathrm{C}$ for $20 \mathrm{~s}$, and $72^{\circ} \mathrm{C}$ for $30 \mathrm{~s}$, followed by a final extension step at $72^{\circ} \mathrm{C}$ for $1 \mathrm{~min}$ in a PTC-200 Thermocycler (MJ Research, Watertown, Mass).

\section{Detection of BCP and precore mutants}

For the detection of BCP and precore mutants, HBV-DNA-positive samples were amplified by using the primers described by Takahashi et al. [26].

\section{Amplification of HBV pre-S region and sequencing analysis}

The pre-S1 and pre-S2 regions were amplified as described previously [19] by heminested PCR with 5'-TCA CCA TAT TCT TGG GAA CAA GA-3' (P1, sense, nucleotides 2817 to 2839) and 5'-GGC ACT AGT AAA CTG AGC CA-3' (S2-2, antisense, nucleotides 668 to 687) for the outer primer pair (1,085 bases) and P1 and 5'-AGA AGA TGA GGC ATA GCA GC-3' (S4R, antisense, nucleotides 415 to 434) for the inner primer pair ( 834 bases). First-round PCR was performed with the following parameters: preheating at $95^{\circ} \mathrm{C}$ for $10 \mathrm{~min}$ to activate the AmpliTaq DNA polymerase, then 40 cycles of amplification at $94^{\circ} \mathrm{C}$ for $20 \mathrm{~s}$, annealing at $55^{\circ} \mathrm{C}$ for $20 \mathrm{~s}$, and extension at $72^{\circ} \mathrm{C}$ for $1 \mathrm{~min}$, and elongation for $7 \mathrm{~min}$ in the last cycle. The second-round PCR was performed in the same conditions for 40 cycles except the annealing temperature was at $60^{\circ} \mathrm{C}$.

The pre-S amplicons were isolated by $1 \%$ agarose gel electrophoresis and purified with the QIA quick gel extraction kit (Qiagen Inc., Chatsworth, Calif.). Recovered PCR products were then subjected to direct sequencing with primers of P1 and S4R, with an ABI Prism Big Dye terminator cycle sequencing ready reaction kit (Perkin Elmer). Sequences of amplified DNA were determined with a sequencer (ABI model 377 and 310; Applied Biosystems, Foster City, Calif.).

\section{Sequence analysis}

Genotyping, BCP, and precore mutant and pre-S region analysis were carried out by sequence comparison with known sequences from different HBV genotypes that have been previously described and were aligned as described above. The Geneious program (Biomatters, Inc.) was used for genotyping as well as for phylogenetic and molecular evolutionary analyses.

\section{HBV DNA quantification}

All samples were submitted to HBV DNA quantification using the commercial TaqMan Amplicor HBV assay (Roche Diagnostics), which has a lower limit of detection of 12 IU/L.

\section{Statistical analysis}

For statistical analysis, we used the PASW Statistics software package, version 18.0. Either the $\chi^{2}$ test with the Yates correction or Fischer's exact test was used to analyze quantitative data and to compare proportions. All calculated P-values were two-tailed and all P-values $<0.05$ were considered to be statistically significant.

\section{GenBank accession numbers}

Sequences from the $S$ gene that were acquired during this study were deposited in the GenBank under numbers GU594063-GU594150.

\section{Results}

\section{Distribution of HBV genotypes}

Of the $120 \mathrm{HBs}$ Ag-Positive subjects, $\mathrm{HBe} \mathrm{Ag}$ was detected in nine serum samples (7.5\%). 90 (75\%) of the $120 \mathrm{HBs}$ Ag-Positive subjects were positive for HBV-DNA in the sera, detected by PCR. The mean age of the subjects was $36.4 \pm 12.6$ years and $82.2 \%$ were male. Of those positive for HBV-DNA, 70 cases $(77.8 \%)$ were determined to be genotype $\mathrm{D}, 16$ cases (17.8\%) belonged to genotype $\mathrm{A}$, and 4 cases (4.4\%) belonged to genotype C. The distribution of the HBV antigen subtypes among these subjects was: ayw2 (78.9\%), adw2 (14.4\%), and adw (2.2\%). In this study, all cases with genotype D belonged to the subtype awy2. The obtained sequences were submitted to GenBank under accession numbers GU594063-GU594150. The sequences were also aligned with those of the isolates of known genotype and subjected to phylogenetic analysis (Figure 1).

\section{Prevalence and characterisation of pre-S mutations}

Based on direct sequencing, pre-S mutations were detected in only four of the 90 cases (4.4\%). All of these cases belonged to genotype C. As for the prevalence of pre-S mutations according to site, pre-S2 deletion was the most common (50\%), followed by both pre-S2 and pre-S1 deletion (25\%), and start codon mutation (25\%). The mean age of patients with a pre-S mutation was significantly higher than that of patients without the mutations $(\mathrm{P}<0.05)$. In addition, the mean HBV load in patients with a pre-S mutation was significantly higher than in those without mutants $(\mathrm{P}<0.05)$. The alignment of amino acid sequences of the entire pre-S1/pre-S2 region of the four samples is shown in Figure 2.

\section{Discussion}

HBV infection is an important global health problem that places a continuously increasing burden on developing countries like the UAE. Molecular epidemiological studies provide valuable information on understanding the prevalence and characteristics of HBV genotypes and mutations from different areas of the world. In this study we confirmed the predominance of genotypes D and A among the HBV strains in the UAE, which accounted for more than $95 \%$ of cases. These findings are not surprising; they reflect the typical genotypes circulating in the area.

Genotype $\mathrm{C}$ was not a prevalent genotype in this area. HBV genotype $\mathrm{C}$ is more commonly associated with severe liver diseases and the development of cirrhosis [27].

The pre-S1 and pre-S2 regions, together with the major hydrophilic region exposed at the surface of $\mathrm{HBV}$ particles, are highly immunogenic and potentially under selective pressure by the immune system [28]. The pre-S1 region contains the binding site for HepG2 cells in the liver membrane [2]. The pre-S2 region bears the binding site for polymerised human serum albumen, which is believed to be involved in the attachment of HBV to the human hepatocyte membrane [29]. Therefore, mutations at the pre-S gene might significantly modify the course of HBV infection [30].

Although the occurrence of HBV with the pre-S deletion mutation in liver diseases patients has recently been reported by several groups, its clinical significance has remained obscure [31-34].

The prevalence of pre-S mutations is variable and considerably 


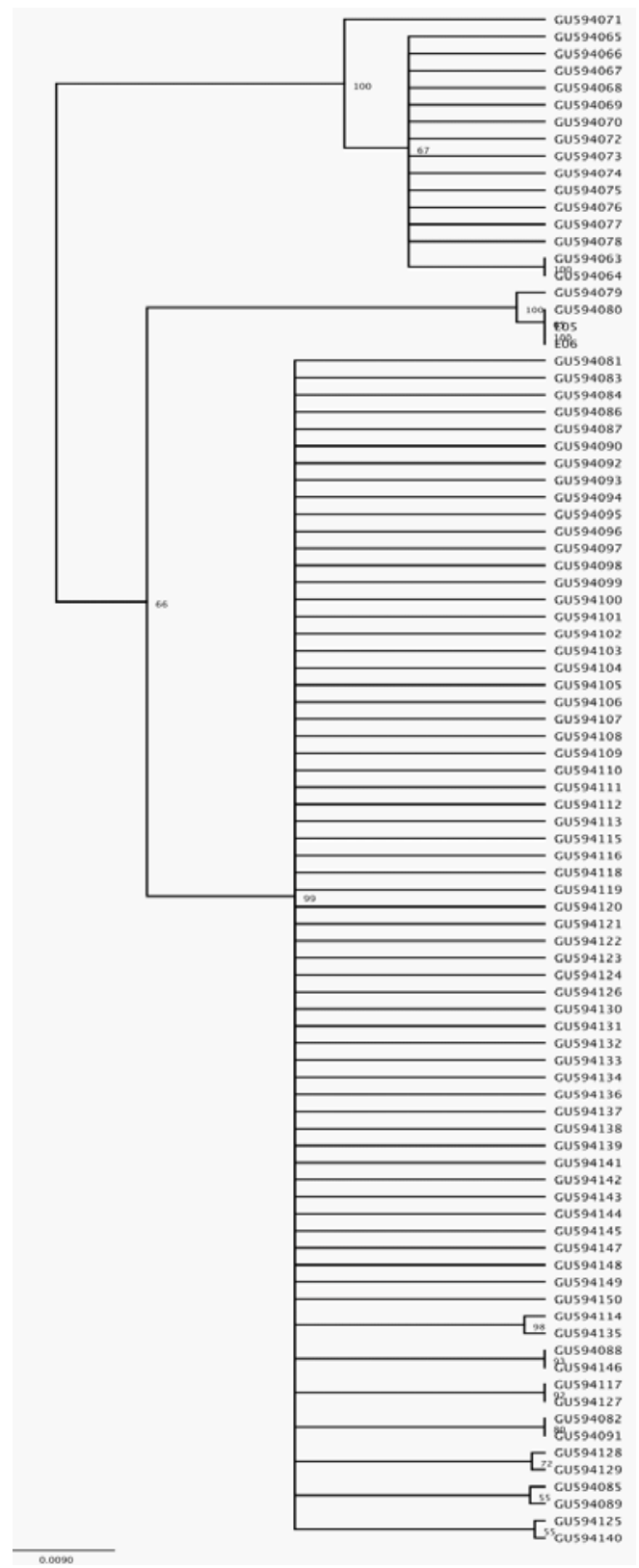

Figure 1: Phylogenetic analysis of the genotype of hepatitis B virus isolated in this study.

different among different geographic areas. In our study it was very low (4.4\%). Huy et al. [19] reported that the prevalence of HBV pre-S mutants ranged from $0 \%$ to $36 \%$ in an analysis of HBV-DNA-positive serum samples from individuals residing in 12 countries (2003). Either no cases or fewer cases with such a mutant were seen in countries with low HBV prevalence and in countries with low prevalence of HBV genotype C.

Interestingly, our data only showed pre-S mutations in patients infected with genotype $\mathrm{C}$. Taking into consideration that these mutations were predominantly found in genotype $\mathrm{C}$, it is possible that this genotype may be more prone to develop such mutations. Moreover, the mean age of patients with pre-S mutations was significantly higher than that

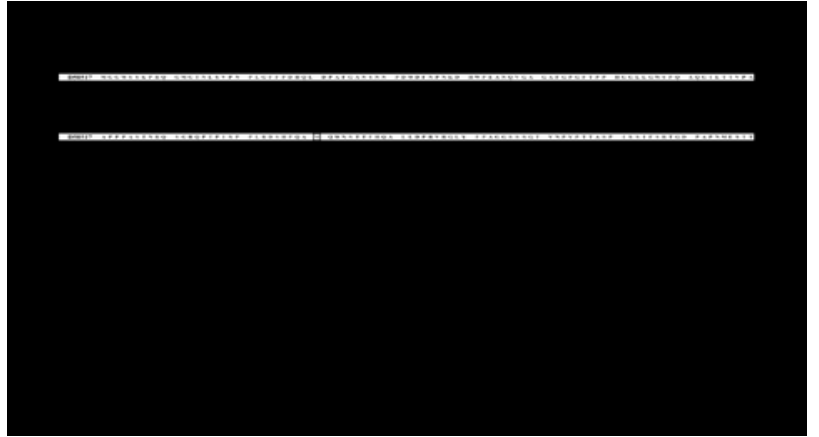

Figure 2: Multi-alignment of the amino acid sequences in the pre-S1 and preS2 genes of the HBV mutations samples.

of those without the mutants. This observation also confirmed previous data suggesting that the prevalence of pre-S mutants tends to increase in direct relation to the patient's age $[15,35,19]$.

Regarding the site of mutation, our report showed that pre-S2 deletion was the most common mutation type. This result is also in agreement with those of recent reports from Japan and Korea [35,19].

In conclusion, our study demonstrates that the HBV genotypes D and $\mathrm{A}$ were the predominant strains circulating in the UAE. We also found that the HBV pre-S mutant is very rare in our area and is only in genotype C.

\section{References}

1. Berthelot P, Neurath R, Courouce AM, Brechot C, Degos F, et al. (1986) Hepatitis $B$ vaccines with pre-S gene product. Lancet 1: 1150.

2. Neurath AR, Kent SB, Parker K, Prince AM, Strick N, et al. (1986) Antibodies to a synthetic peptide from the pres $120-145$ region of the hepatitis $B$ virus envelope are virus neutralizing. Vaccine $4: 35-37$.

3. Neurath AR, Adamowicz P, Kent SB, Riottot MM, Strick N, et al. (1986) Characterization of monoclonal antibodies specific for the pre-S2 region of the hepatitis B virus envelope protein. Mol Immunol 23: 991-997.

4. Przewlocki G, Audibert F, Jolivet M, Chedid L, Kent SB, et al. (1986) Production of antibodies recognizing a hepatitis B virus (HBV) surface antigen by administration of murabutide associated to a synthetic pre-S HBV peptide conjugated to a toxoid carrier. Biochem Biophys Res Commun 140: 557-564.

5. Chisari FV, Pinkert CA, Milich DR, Filippi P, McLachlan A, et al. (1985) A transgenic mouse model of the chronic hepatitis $B$ surface antigen carrier state. Science 230: 1157-1160.

6. Milich DR, McNamara MK, McLachlan A, Thornton GB, Chisari FV (1985) Distinct $\mathrm{H}$-2-linked regulation of $\mathrm{T}$-cell responses to the pre-S and $\mathrm{S}$ regions of the same hepatitis B surface antigen polypeptide allows circumvention of nonresponsiveness to the S region. Proc Natl Acad Sci U S A 82: 8168-8172.

7. Milich DR, Thornton GB, Neurath AR, Kent SB, Michel ML, et al. (1985) Enhanced immunogenicity of the pre-S region of hepatitis $B$ surface antigen. Science 228: 1195-1199.

8. Fan YF, Lu CC, Chang YC, Chang TT, Lin PW, et al. (2000) Identification of a pre-S2 mutant in hepatocytes expressing a novel marginal pattern of surface antigen in advanced diseases of chronic hepatitis B virus infection. J Gastroenterol Hepatol 15: 519-528.

9. Fan YF, Lu CC, Chen WC, Yao WJ, Wang HC, et al. (2001) Prevalence and significance of hepatitis $B$ virus (HBV) pre-S mutants in serum and liver at different replicative stages of chronic HBV infection. Hepatology 33: 277-286.

10. Bréchot C, Hadchouel M, Scotto J, Fonck M, Potet F, et al. (1981) State of hepatitis $B$ virus DNA in hepatocytes of patients with hepatitis $B$ surface antigenpositive and -negative liver diseases. Proc Natl Acad Sci U S A 78: 3906-3910.

11. Hsu T, Möröy T, Etiemble J, Louise A, Trépo C, et al. (1988) Activation of c-myc by woodchuck hepatitis virus insertion in hepatocellular carcinoma. Cell 55 627-635. 
Citation: Alfaresi MS (2012) Molecular Epidemiological Study of Hepatitis B Virus in the United Arab Emirates Based on the Analysis of Pre-S Gene. J Med Microb Diagn 1:113. doi:10.4172/2161-0703.1000113

Page 4 of 4

12. Shafritz DA, Shouval D, Sherman HI, Hadziyannis SJ, Kew MC (1981) Integration of hepatitis $B$ virus DNA into the genome of liver cells in chronic liver disease and hepatocellular carcinoma. Studies in percutaneous liver biopsies and post-mortem tissue specimens. N Engl J Med 305: 1067-1073.

13. Takada S, Gotoh Y, Hayashi S, Yoshida M, Koike K (1990) Structural rearrangement of integrated hepatitis $B$ virus DNA as well as cellular flanking DNA is present in chronically infected hepatic tissues. J Virol 64: 822-828.

14. Hadziyannis S, Gerber MA, Vissoulis C, Popper H (1973) Cytoplasmic hepatitis $B$ antigen in "ground-glass" hepatocytes of carriers. Arch Pathol 96: 327-330.

15. Chen BF, Liu CJ, Jow GM, Chen PJ, Kao JH, et al. (2006) High prevalence and mapping of pre-S deletion in hepatitis $B$ virus carriers with progressive liver diseases. Gastroenterology 130: 1153-1168.

16. Chen $\mathrm{CH}$, Hung $\mathrm{CH}$, Lee $\mathrm{CM}$, Hu TH, Wang JH, et al. (2007) Pre-S deletion and complex mutations of hepatitis $\mathrm{B}$ virus related to advanced liver disease in HBeAg-negative patients. Gastroenterology 133: 1466-1474.

17. Chen $\mathrm{CH}$, Changchien CS, Lee $\mathrm{CM}$, Hung $\mathrm{CH}$, Hu TH, et al. (2008) Combined mutations in pre-s/surface and core promoter/precore regions of hepatitis $\mathrm{B}$ virus increase the risk of hepatocellular carcinoma: a case-control study. J Infect Dis 198: 1634-1642.

18. Fang ZL, Sabin CA, Dong BQ, Wei SC, Chen QY, et al. (2008) Hepatitis B virus pre-S deletion mutations are a risk factor for hepatocellular carcinoma: a matched nested case-control study. J Gen Virol 89: 2882-2890.

19. Huy TT, Ushijima H, Win KM, Luengrojanakul P, Shrestha PK, et al. (2003) High prevalence of hepatitis $B$ virus pre-s mutant in countries where it is endemic and its relationship with genotype and chronicity. J Clin Microbiol 41: 5449-5455.

20. Kajiya Y, Hamasaki K, Nakata K, Nakagawa Y, Miyazoe S, et al. (2002) Fulllength sequence and functional analysis of hepatitis $B$ virus genome in a virus carrier: a case report suggesting the impact of pre-S and core promoter mutations on the progression of the disease. J Viral Hepat 9: 149-156.

21. Preikschat $P$, Günther $S$, Reinhold $S$, Will H, Budde K, et al. (2002) Complex HBV populations with mutations in core promoter, $\mathrm{C}$ gene, and pre-S region are associated with development of cirrhosis in long-term renal transplant recipients. Hepatology 35: 466-477.

22. Santantonio T, Jung MC, Schneider R, Fernholz D, Milella M, et al. (1992) Hepatitis $B$ virus genomes that cannot synthesize pre-S2 proteins occur frequently and as dominant virus populations in chronic carriers in Italy. Virology 188: 948-952.

23. Suwannakarn K, Tangkijvanich P, Thawornsuk N, Theamboonlers A, Tharma- phornpilas P, et al. (2008) Molecular epidemiological study of hepatitis B virus in Thailand based on the analysis of pre-S and S genes. Hepatol Res 38: 244251.

24. Kaneko S, Feinstone SM, Miller RH (1989) Rapid and sensitive method for the detection of serum hepatitis $B$ virus DNA using the polymerase chain reaction technique. J Clin Microbiol 27: 1930-1933.

25. Sitnik R, Pinho JR, Bertolini DA, Bernardini AP, Da Silva LC, et al. (2004) Hepatitis $B$ virus genotypes and precore and core mutants in Brazilian patients. $J$ Clin Microbiol 42: 2455-2460.

26. Takahashi K, Aoyama K, Ohno N, Iwata K, Akahane Y, et al. (1995) The precore/core promoter mutant (T1762A1764) of hepatitis B virus: clinical significance and an easy method for detection. J Gen Virol 76: 3159-3164.

27. Kao JH, Chen PJ, Lai MY, Chen DS (2000) Hepatitis B genotypes correlate with clinical outcomes in patients with chronic hepatitis B. Gastroenterology 118: 554-559.

28. Mimms L (1995) Hepatitis B virus escape mutants: "pushing the envelope" of chronic hepatitis B virus infection. Hepatology 21: 884-887.

29. Pontisso P, Schiavon E, Fraiese A, Pornaro E, Realdi G, et al. (1986) Antibody to the hepatitis $B$ virus receptor for polymerized albumin in acute infection and in hepatitis B vaccine recipients. J Hepatol 3: 393-398.

30. Gerken G, Paterlini P, Manns M, Housset C, Terre S, et al. (1991) Assay of hepatitis $B$ virus DNA by polymerase chain reaction and its relationship to preS- and S-encoded viral surface antigens. Hepatology 13: 158-166.

31. Chen WN, Oon CJ (2002) Pre-S deletion mutants co-exist with wild-type virus at low viral replication stage in Singapore chronic hepatitis B virus carriers. Curr Microbiol 44: 145-147.

32. Pollicino T, Campo S, Raimondo G (1995) PreS and core gene heterogeneity in hepatitis $B$ virus (HBV) genomes isolated from patients with long-lasting HBV chronic infection. Virology 208: 672-677.

33. Tai PC, Suk FM, Gerlich WH, Neurath AR, Shih C (2002) Hypermodification and immune escape of an internally deleted middle- envelope (M) protein of frequent and predominant hepatitis B virus variants. Virology 292: 44-58.

34. Wang YM, Ng WC, Lo SK (1999) Detection of pre-S/S gene mutants in chronic hepatitis B carriers with concurrent hepatitis B surface antibody and hepatitis B surface antigen. J Gastroenterol 34: 600-606.

35. Choi MS, Kim DY, Lee DH, Lee JH, Koh KC, et al. (2007) Clinical significance of pre-S mutations in patients with genotype $C$ hepatitis $B$ virus infection. J Viral Hepat 14: 161-168. 